\title{
CEREBRAL RESPONSE TO HYPOCAPNIA IN NORMAL AND BRAIN-INJURED DOGS
}

\author{
William W. Stoyka, B.SC., M.D., F.R.C.P. $\left(\right.$ c) ${ }^{*}$ \\ and HaRT SChUTZ, M.D., B.SC., F.R.C.s. (c) $\dagger$
}

THE EFFECTS of arterial carbon dioxide tension $\left(\mathrm{PaCO}_{2}\right)$ on the cerebral blood flow (CBF) have been well documented. ${ }^{1,2} \mathrm{~A}$ decrease in $\mathrm{PaCO}_{2}$ (hypocapnia) causes decreased $\mathrm{CBF}$ and increased cerebro-vascular resistance or vasoconstriction. Clinically, intermittent positive pressure is used to produce hypocapnia and vasoconstriction, and thereby decrease cerebral blood flow. However, ventilationinduced hypocapnia is associated with cardiopulmonary changes such as raised mean intrathoracic pressure, decreased venous return with subsequent increase in central venous pressure, and decreased cardiac output. ${ }^{3,4,5}$ To assess the effects of hypocapnia alone on CBF, it is necessary to separate these associated cardiopulmonary changes. Two different methods can be used to induce hypocapnia. Increased volume hyperventilation (IVH) is clinically produced by stepwise elevations in tidal volumes or frequency and is associated with consequent cardiopulmonary changes. Constant volume hyperventilation ( $\mathrm{CVH}$ ) is produced by initial hyperventilation and simultaneous insertion of mechanical deadspace such that the $\mathrm{PaCO}_{2}$ starts at normal levels. Incremental removal of mechanical dead space then produces hypocapnia devoid of associated cardiopulmonary changes because the only variable is the changing $\mathrm{PaCO}_{2}$.

The purpose of this study was to compare the response of $\mathrm{CBF}$, cerebrospinal fluid pressure (CSFP) and cerebral metabolic rate of oxygen $\left(\mathrm{CMRO}_{2}\right)$ against the two methods of hypocapnia in normal and brain-injured dogs.

\section{METHODS}

Fourteen dogs were induced with thiopentone $5 \mathrm{mgm} / \mathrm{kgm}$, the trachea intubated and ventilation controlled with a Harvard animal ventilator. A Godart infra-red analyzer continuously monitored end-tidal carbon dioxide levels. Anaesthesia was maintained with ketamine $2 \mathrm{mgm} / \mathrm{kgm}$. Previous workers have shown that a thiopentone induction and ketamine maintenance closely approximate normal CBF and normal cerebrovascular resistance. ${ }^{6}$ The femoral artery was cannulated for determining arterial pressure, arterial blood gas analyses and haematology sampling. The femoral vein was cannulated and a \#7F thermodilution cardiac output catheter was inserted up to the pulmonary artery. This catheter allowed thermodilution cardiac output determination and central venous

*Assistant Professor, Department of Anaesthesia, University of Toronto, St. Michael's Hospital, Toronto.

$\nmid$ Department of Neurosurgery, Toronto Western Hospital, Toronto.

Address reprint requests to Dr. Stoyka. 


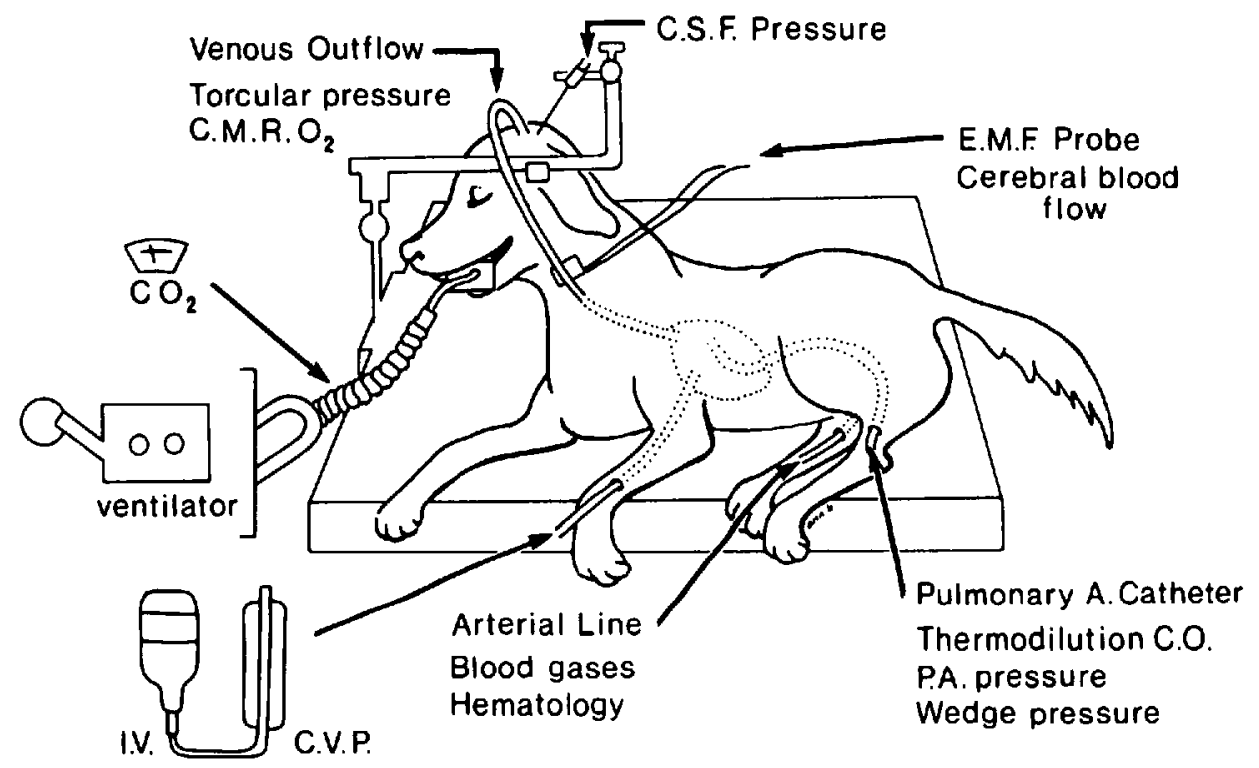

Frgure 1. This illustrates the methodology and parameters to be measured in this study.

pressure measurement. The animals were placed in a stereotactic head frame. A sagittal incision exposed the cranial muscle which was stripped from the skull, and bleeders were coagulated or sealed with bone wax, to effectively remove intracranial-extracranial vascular exchange. A burr hole was placed over the superior sagittal sinus. The sinus was cannulated and shunted to the external jugular vein. A $3-\mathrm{mm}$ electromagnetic flow probe was placed on this shunt to measure blood flow from the sagittal sinus.

Four burr holes were drilled to expose the two petrosal sinuses and the two transverse sinuses according to the method of Rapela and Green. ${ }^{7}$ All sinuses were entered and occluded so that all cerebral venous blood went out through the superior sagittal sinus and the attached shunt. All animals were heparinized after the shunt was in place. Blood transfusions of dog blood were given to replace surgical loss and maintain stable haemoglobin levels. This method of continuous cerebral blood flow measurement has been compared with radioactive xenon studies using the vertebral artery in the dog. ${ }^{8}$ The xenon results have been shown good correlation with the method of Rapela and Green.

A venous transducer was used to monitor venous torcular outflow pressure. A spinal needle was inserted in the cisterna magna and CSFP was measured. Arterial and venous torcular $\mathrm{PO}_{2}, \mathrm{PaCO}_{2}$, and $\mathrm{pH}$ were measured with Radiometer electrodes. Haemoglobin and oxygen saturation were measured with an IL Co-oximeter and the $\mathrm{O}_{2}$ content calculated. The $\mathrm{CMRO}_{2}$ was calculated from the product of the CBF and the arterial-venous oxygen content difference. Figure 1 illustrates the methodology and the parameters which were measured in our study.

Cerebral autoregulation was checked before any measurements were obtained. Mean systemic arterial pressure was raised by $30 \mathrm{~mm} \mathrm{Hg}$ with an angiotensin infusion. Cerebral blood flow was shown to increase as expected. When CBF 


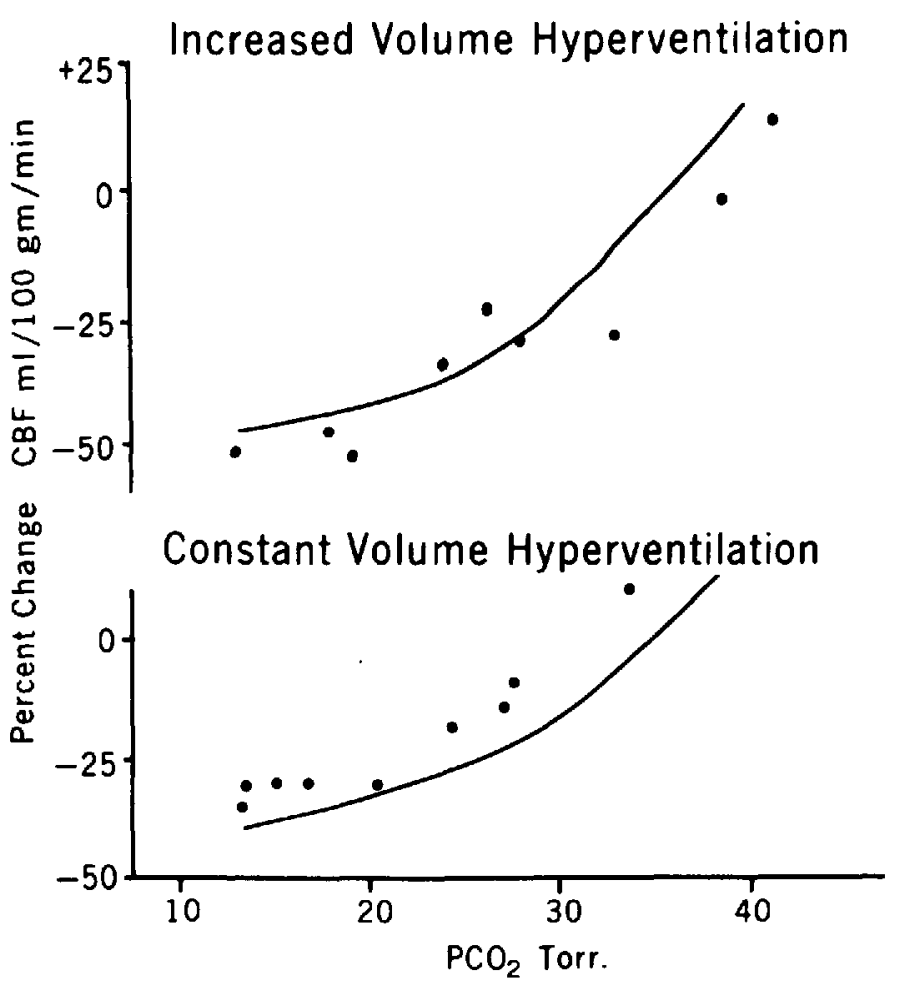

Figure 2. Data from two experiments is shown superimposed on the mean CBF response curve to $\mathrm{PaCO}_{2}$ change in control animals with IVH and $\mathrm{CVH}$.

returned to normal within three minutes, auto-regulation was considered to be intact.

This study was divided into two parts. In the first group the response of CBF, CSFP, and $\mathrm{CMRO}_{2}$ to the two types of hypocapnia was measured in 14 dogs. Seven animals received increased volume hyperventilation (IVH) and seven received constant volume hyperventilation $(\mathrm{CVH})$. Incremental changes in tidal volume, frequency or mechanical dead space removal occurred at 20 -minute intervals. In the second part, the $10 \mathrm{dogs}$. were induced with pentobarbitone and allowed to breathe spontaneously on room air. A $1.5-\mathrm{cm}$ temporal burr hole was made and a sealed copper tube applied to the dura. Liquid nitrogen was poured into the tube for five minutes. A brass plug with an orifice was placed on the burr hole and the surgical incision was closed. The animals were allowed to recover overnight and returned the following day. At this point the animals were anaesthetized and monitored similar to the control group. Extradural pressure was monitored through the orifice of the brass plug. Five animals received IVH and five received CVH. At the end of each study, the skull was opened and biopsies obtained at the lesion, adjacent to the lesion at variable distances and on the opposite hemisphere. The animals were sacrificed and the brain removed and weighed. Brain biopsies were sent for electron microscopy for further analyses. 


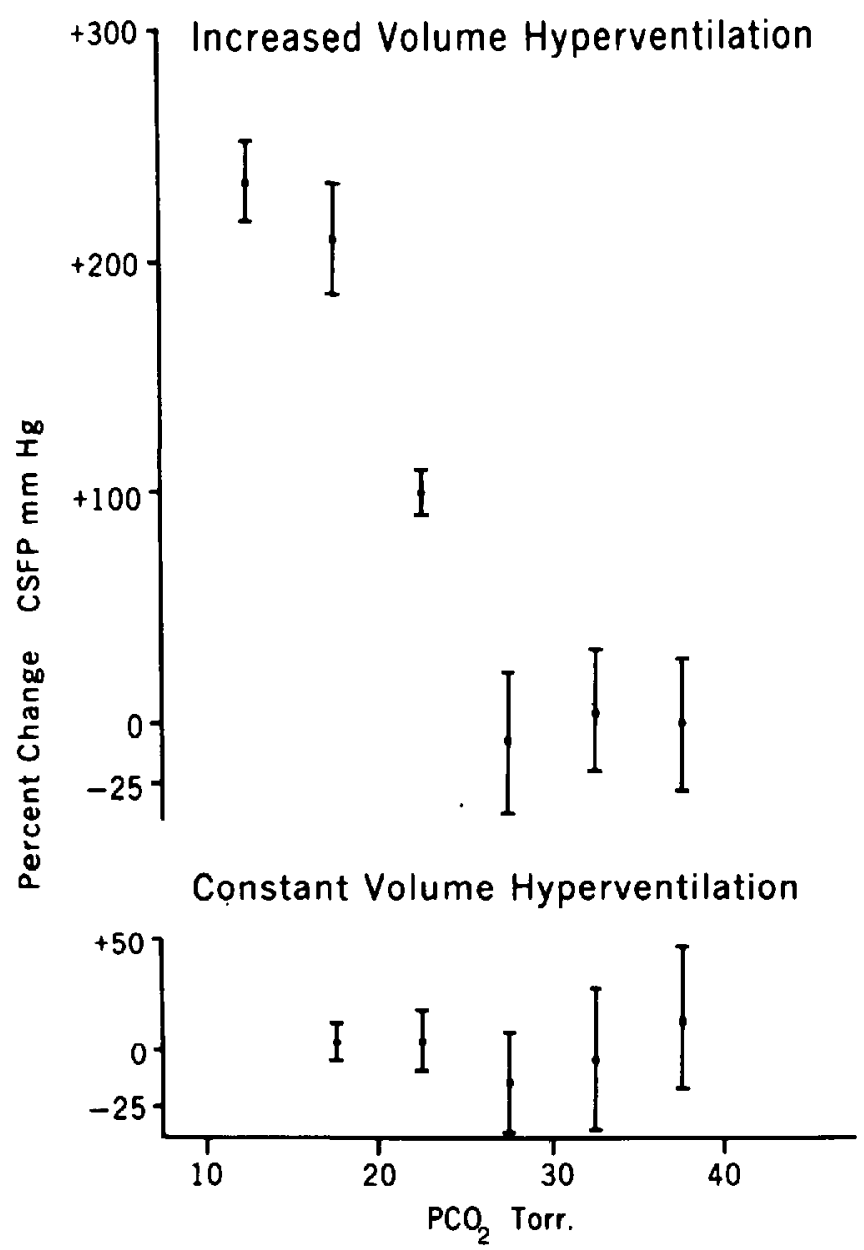

Figure 3. This represents the response of CSFP to changing $\mathrm{PaCO}_{2}$ in control animals with IVH and CVH.

\section{Results and Discussion}

The response of $\mathrm{CBF}$ to altered $\mathrm{PaCO}_{2}$ in control animals is shown in Figure 2. Sample data from two experiments are superimposed on the CBF response curves obtained from all animals. The average CBF was $44.2 \pm 4.7 \mathrm{ml} / 100$ $\mathrm{gm} / \mathrm{min}$, at a $\mathrm{PaCO}_{2}$ of $40 \mathrm{~mm} \mathrm{Hg}$. The $\mathrm{CBF}$ decreased 1.77 per cent per mm $\mathrm{Hg}$. $\mathrm{PaCO}_{2}$ on the linear portion of the $\mathrm{CBF}$ response curve between $\mathrm{PaCO}_{2}$ values of 70 down to $25 \mathrm{~mm} \mathrm{Hg}$. Our graph documents only changes found below a $\mathrm{PaCO}_{2}$ of 40 , although data was obtained to $\mathrm{PaCO}_{2}$ values of $115 \mathrm{~mm}$ $\mathrm{Hg}$. The value of 1.77 per cent change per $\mathrm{mm} \mathrm{Hg} \mathrm{PaCO}_{2}$ is comparable to the value of 2 per cent change obtained by Reivich. ${ }^{1}$ The rate of $\mathrm{CBF}$ change decreased at levels below $25 \mathrm{~mm} \mathrm{Hg}$ and plateaued at values of $18-20 \mathrm{~mm} \mathrm{Hg}$ as maximum cerebral vasoconstriction was approached. No significant difference was seen in the response of CBF to either IVH or CVH.

Figure 3 represents the response of CSFP to altered $\mathrm{PaCO}_{2}$ in control aninals. 


\section{Increased Volume Hyperventilation}

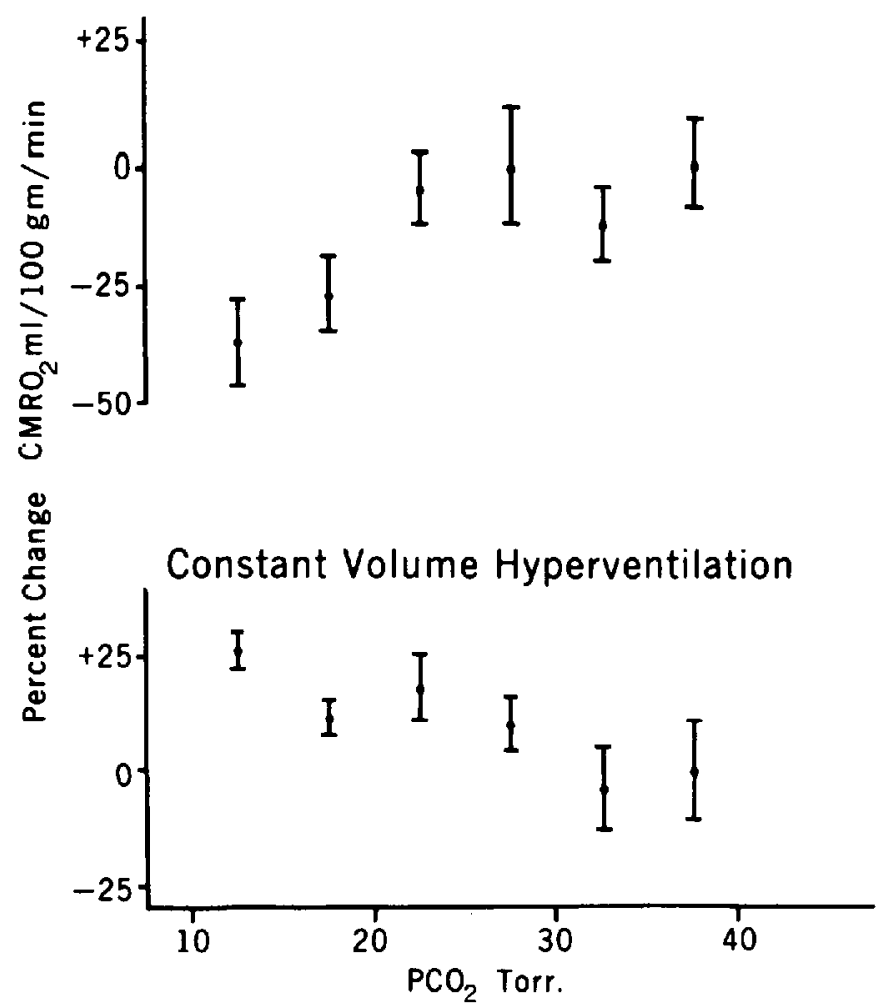

Figure 4. A comparison of $\mathrm{CMRO}_{2}$ with changing $\mathrm{PaCO}_{2}$ is shown in control animals with IVH and CVH.

IVH produced progressive increases in CSFP. This was expected due to raised mean intrathoracic pressure, raised central venous pressure, decreased cardiac output and decreased cerebral perfusion pressure. The parameters were monitored and documented in all control animals. CVH produced little change in CSFP because of the constancy in cardiopulmonary parameters. The mean intrathoracic pressure and central venous pressure were stable while cardiac output and cerebral perfusion pressure decreased to a lesser extent than with IVH. The baseline CSFP with CVH was higher than IVH due to increased airway resistance associated with a large volume of mechanical dead space.

The $\mathrm{CMRO}_{2}$ or oxygen consumption has been shown to be affected by anaesthesia, hyperventilation, hypotension, hypoxia and trauma. The $\mathrm{CMRO}_{2}$ in our study was $3.3 \mathrm{mls} / 100 \mathrm{gm} / \mathrm{min}$ at a $\mathrm{PaCO}_{2}$ of $40 \mathrm{~mm} \mathrm{Hg}$ in control animals. This value was higher than results obtained with other forms of anaesthesia ${ }^{12}$ but closely approximated normal baseline values obtained in unanaesthetized dogs. This substantiated the work of Dawson et al. ${ }^{6}$ A stable $\mathrm{CMRO}_{2}$ is normally maintained by the brain by increasing oxygen extraction by train tissue. A falling or decreased $\mathrm{CMRO}_{2}$ has been shown to be a useful prognostic guide to tissue 


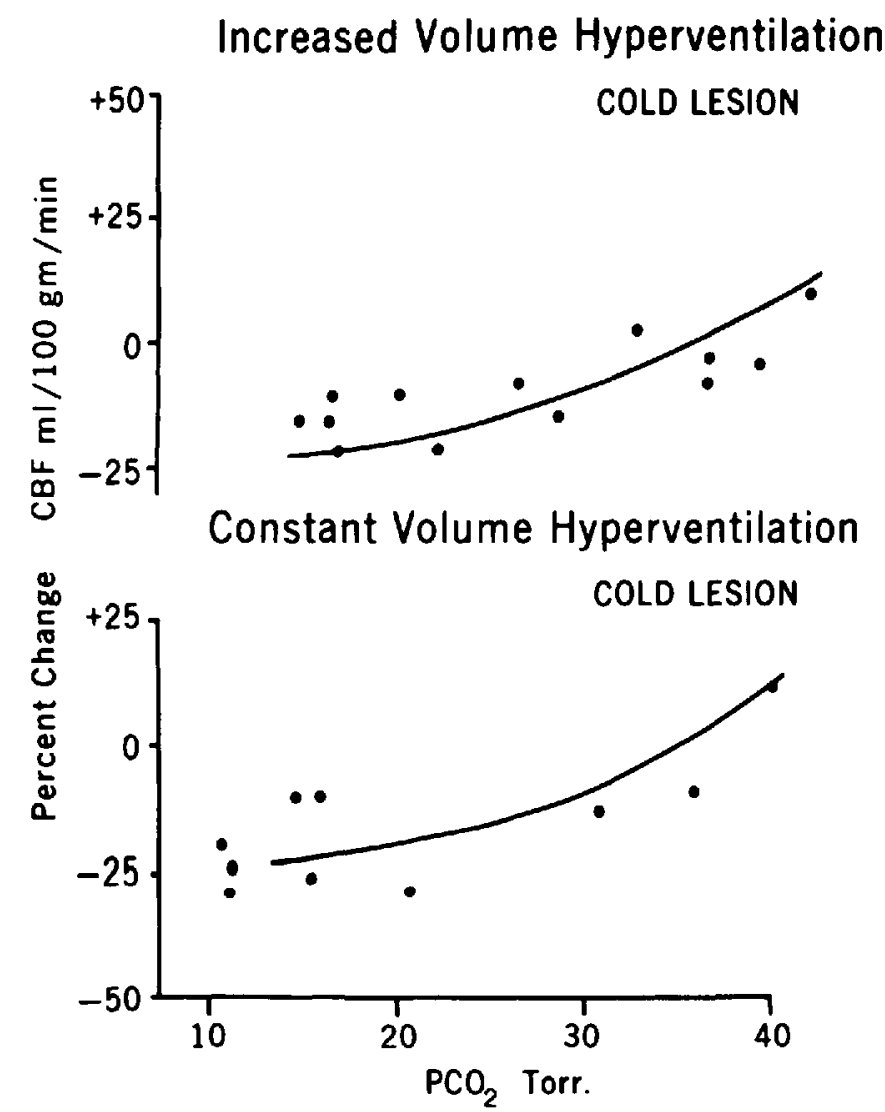

Figure 5. This represents the response of $\mathrm{CBF}$ to $\mathrm{PaCO}_{2}$ changes in brain lesion dogs with IVH and CVH. Sample data from two experiments are superimposed on the mean CBF response curve.

hypoxia or brain trauma. ${ }^{9}$ This change in $\mathrm{CMRO}_{2}$ was documented by measuring the arterio-venous oxygen difference and $\mathrm{CBF}$. Figure 4 shows that dogs receiving $\mathrm{CVH}$ showed no evidence of decreased $\mathrm{CMRO}_{2}$ with decreasing $\mathrm{PaCO}_{2}$ values. There is no evidence of brain hypoxia even at very low $\mathrm{PCO}_{2}$ values. Tissue extraction of oxygen continued as shown by widened arterio-venous oxygen differences. Dogs receiving IVH started to show evidence of tissue hypoxia at $\mathrm{PaCO}_{2}$ values below $20 \mathrm{~mm} \mathrm{Hg}$. The cause of tissue hypoxia with IVH was related to decreased cerebral perfusion pressure, raised CSFP, decreased cardiac output and decreased systemic arterial pressure; changes which were minimized with CVH. The result was inhomogeneous perfusion of brain tissue occurring with IVH.

After comparing the response of CBF, CSFP, and $\mathrm{CMRO}_{2}$ to IVH and CVH in normal dogs, a comparison was made with animals in which a standardized cold lesion was induced and the same parameters measured. Figure 5 represents the response of $\mathrm{CBF}$ to altered $\mathrm{PaCO}_{2}$ in brain lesion animals. The average $\mathrm{CBF}$ was $32.7 \pm 4.9 \mathrm{ml} / 100 \mathrm{gm} / \mathrm{min}$ at a $\mathrm{PaCO}_{2}$ of $40 \mathrm{~mm} \mathrm{Hg}$ compared to 44.2 in control animals. $\mathrm{CBF}$ decreased at the rate of $0.6 \% / \mathrm{mm} \mathrm{Hg}$ change in $\mathrm{PaCO}_{22}$ 


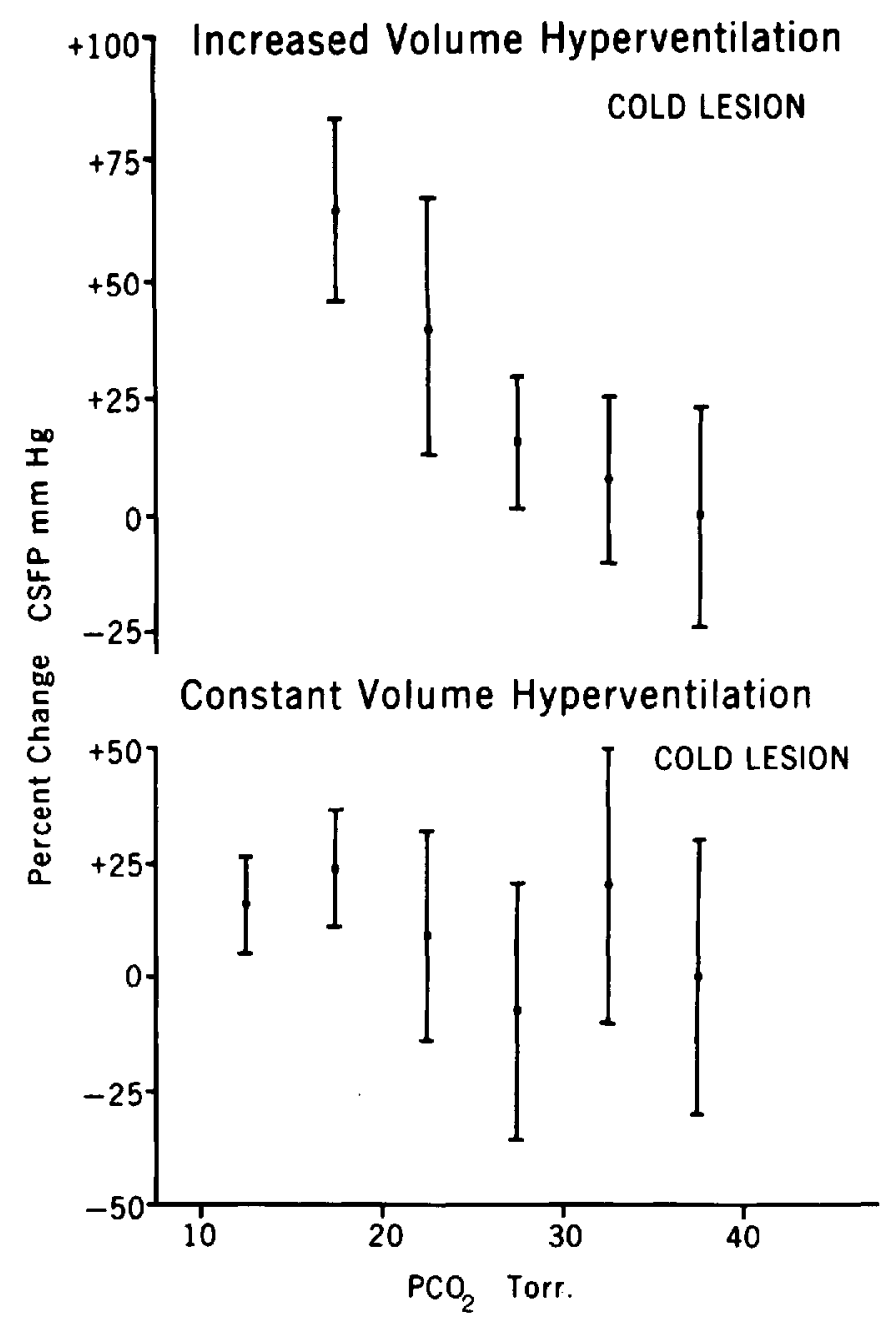

FIcune 6. The response of CSFP to changing $\mathrm{PaCO}_{2}$ is shown in brain lesion dogs with IVH and CVH.

compared to the normal value of 1.7 per cent indicating altered carbon dioxide reactivity. The decreased $\mathrm{CBF}$ and altered reactivity were due to the area of infarcted brain tissue surrounded with areas of reactive hyperaemia and ischaemia. Pathological sections examined under electron microscopy showed areas of reactive hyperaemia adjacent to the infarcted areas with areas of ischaemia outside areas of reactive hyperaemia. All brain biopsies were taken at low $\mathrm{PaCO}_{2}$ at the end of the experiment. The resultant information adds evidence to the work of Yamaguchi and Walt ${ }^{10}$ who documented changes in experimental brain lesions measuring regional CBF.

The response of CSFP to altered $\mathrm{PaCO}_{2}$ in brain lesion dogs is shown in Figure 6. The baseline CSFP averaged $7.1 \mathrm{~mm} \mathrm{Hg}$ above levels obtained in control dogs due to induced trauma and resultant oedema. Although the base- 
Increased Volume Hyperventilation

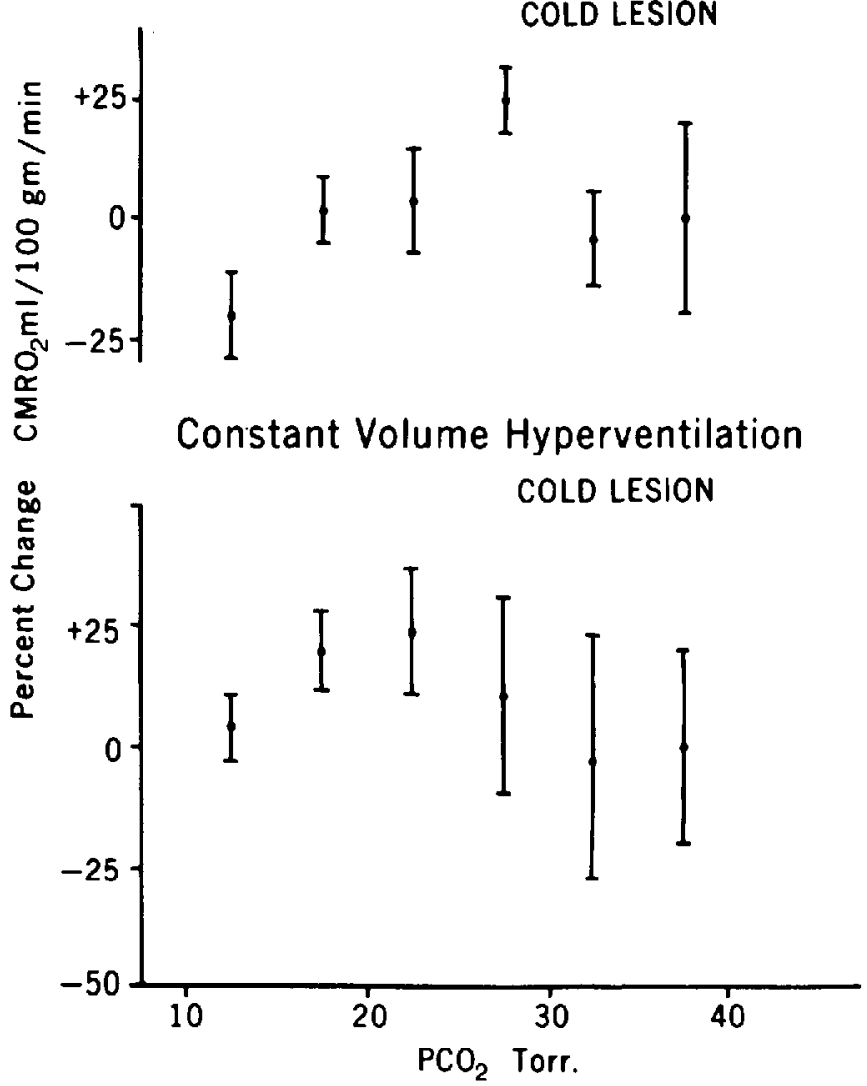

Ficure 7. A comparison of $\mathrm{CMRO}_{2}$ with changing $\mathrm{PaCO}_{2}$ is shown in brain lesion dogs with IVH and CVH. Baseline depression is the only difference from figure 4.

line CSFP was higher, the magnitude of change in CSFP to $\mathrm{PaCO}_{2}$ differed slightly with control dogs. Cold lesion dogs showed reduced rises in CSFP when compared to Figure 3. IVH showed significant CSFP changes due to altered cardiopulmonary dynamics as previously described in control animals; whereas CVH showed little change with more stable cardiopulmonary parameter measurements.

Brain lesion dogs exhibited an expected decrease in $\mathrm{CMRO}_{2}$ due to cerebral infarction. The average $\mathrm{CMRO}_{2}$ was $2.6 \mathrm{ml} / 100 \mathrm{gm} / \mathrm{min}$ at a $\mathrm{PaCO}_{2}$ of $40 \mathrm{~mm}$ $\mathrm{Hg}$ compared to 3.3 in control animals. This represented a 22 per cent decrease due to a standard lesion. Figure 7 shows the response of $\mathrm{CMRO}$. to altered $\mathrm{PaCO}_{2}$ was similar to control dogs. $\mathrm{CVH}$ produced no significant change in $\mathrm{CMRO}_{2}$. Dogs receiving IVH started to show evidence of hypoxia at $\mathrm{PaCO} 2$ values below $20 \mathrm{~mm} \mathrm{Hg}$ similar to control animals. In lesion dogs, IVH subjected an already impaired brain to even greater hypoxia when $\mathrm{PaCO}_{2}$ levels fell below $20 \mathrm{~mm} \mathrm{Hg}$. Also, $\mathrm{CMRO}_{2}$ changes do not take into consideration areas of regional hypoxia due to luxury perfusion or Robin Hood syndrome with altered $\mathrm{PaCO}_{2}$. 
The end result of these variables could be greater tissue hypoxia then recorded by $\mathrm{CMRO}_{2}$ changes.

\section{SumMary}

The cerebral blood flow response to hypocapnia was quantitated utilizing two methods of ventilation. Increased volume hyperventilation produced hypocapnia and decreased $\mathrm{CBF}$ but was associated with cardiopulmonary changes which raised mean intrathoracic pressure, decreased venous return and decreased cardiac output. This resulted in increased CSFP, decreased cerebral perfusion pressure and decreased $\mathrm{CMRO}_{2}$ at $\mathrm{PaCO}_{2}$ values below $20 \mathrm{~mm} \mathrm{Hg}$ which was indicative of hypoxia. Constant volume hyperventilation with incremental removal of mechanical dead space was considered as hypocapnia where $\mathrm{PaCO}$. was the singular variable because associated cardiopulmonary changes were minimized. This resulted in no CSFP changes and no changes in $\mathrm{CMRO}_{2}$ even at low $\mathrm{PaCO}_{2}$ values below $20 \mathrm{~mm} \mathrm{Hg}$.

It is concluded that hypocapnia per se does not produce brain tissue hypoxia in normal or brain injured dogs. Hypoxia secondary to hypocapnia is the result of the associated cardiopulmonary and cerebrovascular changes associated with mechanical hyperventilation.

\section{RÉSUMÉ}

La réponse vasculaire cérébrale à l'hypocapnée fut investiguée par deux techniques de ventilation. D'une part, l'hyperventilation à grand volume produit une hypocapnée, diminue le flot vasculaire cérébral, mais s'accompagne d'une augmentation de la pression intra-thoracique moyenne, d'une diminution du retour veineux et du débit cardiaque. Ceci se solde par une augmentation de la pression du L.C.R., par une diminution de la pression de perfusion cérébrale et du C.M.R. $\mathrm{O}_{2}$ à une $\mathrm{PaCO}_{2}$ inférieure à $20 \mathrm{~mm} \mathrm{Hg}$ qui signale une hypoxie.

D'autre part, une hyperventilation à volume constant avec diminution marquée de l'espace mort fut considérée comme hypocapnée où la $\mathrm{PaCO}_{2}$ se présente comme la seule variable puisque les changements cardio-pulmonaires furent minimes. Nous retrouvons aucune variation de la pression du L.C.R., de la C.M.R. $\mathrm{O}_{2}$ à une $\mathrm{PaCO}_{2}$ inférieure à $20 \mathrm{~mm} \mathrm{Hg}$.

L’hypocapnée per se n'apporte donc aucune hypoxie tissulaire cérébrale chez le chien normal ou lésé au point de vue cérébral. L'hypoxie secondaire à l'hypocapnée est le résultat de changements cario-pulmonaires ou cérébro-vasculaires associés à l'hyperventilation mécanique.

\section{ACKNOWLEDGMENTS}

The authors wish to acknowledge the assistance of the Anaesthesia Research Laboratory, St. Michael's Hospital, under the direction of Chief Technician, Mr. Colin Kay. This study was supported in part by the St. Michael's Hospital Research Society and the Ontario Heart Foundation which made thermodilution cardiac outputs possible for routine measurement. Parke-Davis gratuitously supplied Ketalar for research purposes. 


\section{REFERENCES}

1. Reivich, M. Arterial $\mathrm{PCO}_{2}$ and cerebral hemodynamics. Amer. J. Physiol. 206: 25-35 (1964).

2. Raichle, M.E., Posner, J.B., \& Prum, F. Cerebral blood flow during and after hyperventilation. Arch. Neurol. 33: 394-403 (1970).

3. Counnand, A., Motley, H.L., Werko, C., \& Richards, D.W., Jr. Physiological studies of the effects of intermittent positive pressure breathing on cardiac output in man. Am. J. Physiol. 152: 162 (1948).

4. Morgan, B.C., Crawford, E.W., Hornbein, T.F., Mahtin, W.E., \& Guntheroth, W.G. Hemodynamic effects of changes in arterial carbon dioxide tension during intermittent positive pressure ventilation. Anesthesiol, 28: 866 (1967).

5. Morgan, B.C., Martin, W.E., Hornbein, T.F., Crawford, E.W.. \& Guntheroth, W.G. Hemodynamic effects of intermittent positive pressure respiration. Anesthesiology 27: 584-590 (1966).

6. Dawson, B., MichENFELder, J.D., \& THEYE, R.A. Effects of ketamine on canine cerebral blood flow and metabolism: modification by prior administration of thiopental. Anesth. \& Analg. 50: 443-447 (1971).

7. RAPELA, C.E. \& GREEN, H.D. Autoregulation of canine cerebral blood flow. Suppl. I. Circ. Res. Vol. XIV and SV. 205-41 (1964).

8. Bruce D., Schutz, H., \& LangFitT, T. 1972 (personal communication).

9. Tababaddor, K., Bhushan, C., Pevsner, P.A., \& Walker, A.E. Prognostic value of $\mathrm{CBF}$ and $\mathrm{CMRO}_{2}$ in acute head trauma. J. of Trauma: 12: No. 12, 1053-1055 (1972).

10. Yamaguchi, T., Regli, $\mathbf{F}$., \& Waitz, A.C. Effect of $\mathrm{PaCO}_{2}$ on hyperemia and Ischemia in experimental cerebral infarction. Stroke: 2: 139-147 (1971).

11. Harp, J.R. \& Wollman, H. Cerebral metabolic effects of hyperventilation and deliberate hypotension. Brit. J. Anaesth. 45: 256-262 (1973).

12. Fink, B.R. \& Haschre, R.H. Anaesthetic effects on cerebral metabolism. Anesthesiology 39: 199-215 (1973). 